\title{
CINDERELLA COMPLEX: A META-ANALYTIC REVIEW
}

\author{
Jeslin Babu Joseph* Sanjaly Jayesh* Sannet Thomas** \\ *I MSc psychology students, Yuvakshetra Institute of Management Studies, Mundur, Palakkad, \\ Kerala, Pin: 678631 \\ **Assistant Professor of Yuvakshetra Institute of Management Studies, Mundur, Palakkad, \\ Kerala, Pin: 678631
}

Article DOI: $\underline{\text { https://doi.org/10.36713/epra6596 }}$

DOI No: 10.36713/epra6596

\begin{abstract}
Women's dependency has been a widely debated topic all over the world. A woman is always expected to do only what is appropriate in contemporary society since infancy, and they are not prepared for independence or self-sufficiency from the moment they are born. The idea of female dependency began to cause confusion and discontent among the "new independent women". The fear of being independent then termed as the Cinderella Complex. Cinderella Complex refers to the fear of being independent, causes unconscious desire to be taken care of by others $\quad$ (C. Dowling, 1981). Here the investigator planned to go through the studies conducted in India as well as outside to have a deep understanding on the concept of Cinderella Complex, its dimensions, method of study, related concepts, implications etc. The investigators used meta-analysis as the method for approaching the problem. Six studies which met the inclusion criteria were selected for this study. Findings of the study show that it is interpreted that women having high scores in Cinderella Complex are bound to show negative motivation towards personal growth. Furthermore, an interventional approach is being developed to motivate and train young women towards personal growth.
\end{abstract}

KEYWORDS: Cinderella complex, Meta-analysis, Women, Dependency

\section{INTRODUCTION}

Cinderella complex is defined as the fear of being independent causes unconscious desire to be taken care of by others (Segen's medical-dictionary, 2011). The Cinderella complex was first proposed by Colette Dowling, who wrote a book on women's fear of independence - an unconscious desire to be taken care of by others. As a person gets older, the complex is said to become more evident. Dowling seeks to describe women as being driven by an implicit desire to be cared for as well as a fear of freedom, which he refers to as the "Cinderella complex." Women have been told since the dawn of time that they must support men emotionally and financially. Usually, patriarchal society persuades women that this system was founded for their comfort (Saha and Safri, 2016). Women, on the other hand, are at risk of losing their selfconfidence due to their low sense of status. From the 1950 s to the 1970 s, sociologists focused on women's rights and equality. Nonetheless, they believed in gender differences or separate roles. They connected motherhood to women's natural impulses without taking into account their pain and anxiety. As a result, girls develop a distrust of men. In fact, the origin of this fear comes from the notion of femininity (Nerenberg, 2017). Girls are taught that femininity and dependence are inextricably related. This dependence, on the other hand, creates a hierarchical society in which women are neither superior nor equal to men.

Cinderella Complex takes its name from the Cinderella fairy tale princess who waits for her prince charming to save her from her wicked stepmother and 
stepsisters. The majority of modern fairy tale adaptations, as well as the original versions, impose gender constraints on women. Cinderella by Perrault is an example of how the heroine of the story must be "rescued" by a princely matter and supported by outwardly powers in order to obtain recognition and respect. Cinderella has no bad feelings toward her oppressors, the stepsisters and stepmother. This plot tells a woman that the only way to conquer injustice is to be patient and noble, and to wait for the day when the reward for her perseverance comes in the form of a man. As a result, young women are socialised to be dependent. Its plot is based on the notion that women should be "beautiful, friendly, elegant, industrious, compliant, and passive."According to the Medical Dictionary (2011) Cinderella Complex is termed as the fear of being independent causes unconscious desire to be taken care of by others. The belief that an ideal man would take care of all of a woman's needs and wants makes her submissive. A helpless girl living in a depressed society, like Cinderella, must wait for her dream knight on a white horse to come along and satisfy all of her wishes. This helps to reinforce the notion of what it means to be a normal girl. For instance, young girls should play with dolls; this keeps up ideas of motherhood and domestic activities (Bressler, 2012, p. 135). Cinderella is a patriarchal weapon that produces and nurtures psychological dependency in women. The attributes of feminine beauty and virtue are inextricably connected to those of conscience. A woman must be attractive, faithful, patient, sacrificial, and sexually innocent in order to be virtuous. A woman feels bad if she lacks any of these feminine qualities As a consequence, dependence becomes a source of relief from perceived suffering. Rather than being self-sufficient, women depend on a man for security, identification, and proof of love. Feminist movements have existed in different ways all over the world. The world is awash in slogans calling for women's rights and equality, but what the general public overlooks is the psychological transference of dependence on men that women have built over time. Every female baby is still taught that she will never have to face danger because she will still be safe. This psyche transforms into a need for men's help and a dependence on them for protection. Furthermore, the Cinderella complex is not only seen in the sense of housewives or women who lack understanding. Cinderella Complex can be seen in women who are goal-oriented and making a lot of money. Diane Richardson assumes that "in conventional sociology and popular culture, motherhood was assumed to be a natural female desire and part of obtaining full adult status as a normal woman (Woodward, 1994, p. 14)". Dependency can be seen in cases where the wife seeks guidance from her husband and looks to him for all of her decisions. All women have Cinderella Complex tendencies, but those with high Cinderella Complex scores are especially troubling. These women have a narcissistic dependency on men, which can be exhausting for their male partners and self-destructive for them. This leads to unreasonable expectations, which lead to disappointment. Cinderella is the name of the fairy tale heroine who influenced the creation of the complex. It is based on the idea of femininity portrayed in that story, where a woman is beautiful, graceful, polite, supportive, hardworking, independent, and maligned by the females of her society, but she is not capable of changing her situations with her own actions and must be helped by an outside force, usually a male (i.e., the Prince)( C. Dowling, 1981).

\section{THEORY OF CINDERELLA COMPLEX}

Colette Dowling is an American author that describes Cinderella Complex and she is best known as the first author who describes the term with her book entitled The Cinderella Complex: Women's Hidden Fear of Independence (1981). Dowling writes about her personal experiences as a woman who experiences the Cinderella Complex itself. She identifies herself as a strong and independent woman who has shown for years that she is capable of supporting herself and pursuing her career in the manner she desires. However, after her marriage, she explains a shift in her emotions, in which she wishes to be fully supported by her husband and no longer consider having a job. Dowling is depressed as a result of her new lifestyle, and she holds her husband responsible for her depression. Her husband is the one who awakens her to the fact that she has been living in luxury, expecting her husband to take care of everything. After she realizes how helpless she is, Dowling tries to gets her freedom again, yet she realizes that the only way she can stand up straight is if someone lifted her up (Dowling, 1981).Dowling states that dependency needs is still normal if it is in acceptable point. Men and women are still considered appropriate to be cared for by others as long as they are still in a tolerable condition. There is, however, a distinction between men and women. Dowling writes in her book that: It is preparation, not nature, that bestows this selfsufficiency on men. Males are raised to be selfsufficient from the moment they are born. Females are taught in a similar way that they have a way out - that they will be rescued someday, in some way. That is the fairy tale, the life-message we have interjected as if with mother's milk (Dowling, 1981).According to Dowling, since childhood women have been encouraged to be dependent even to an unhealthy 
degree (Dowling, 1981). Thus, in adulthood, when a woman finds the freedom in life, she will find that the freedom is frightening because she has many opportunities to do anything or to be anything she wants but she is not ready for all of it. Later, Dowling discovers that the fears of being independent comes from the psychological need to avoid it, Dowling calls it the "wish to be saved" (Dowling, 1981). As she states that: We were brought up to depend on a man and to feel naked and frightened without one. We were taught to believe that as women we cannot stand alone, that we are too fragile, too delicate, and needful of protection. So that now, in these enlightened days, when our intellects tell us to stand on our own two feet, unresolved emotional issues drag us down. At the same time that we yearn to be fetterless and free, we also yearn to be taken care of (Dowling, 1981). Dowling's concept of Cinderella Complex as repressed attitudes and fears correlates to Sigmund Freud's psychoanalysis theories. Dowling claims that women's fear about freedom has been present since childhood, and that it is difficult to be free of these emotions, so women prefer to bury them deep inside their subconscious minds. Furthermore, since the family is the source of human's early emotional experience, it is clear that the family will have a huge effect on their children's attitudes, actions, and what kind of adult they will become in the future. Dowling's concept of Cinderella Complex, in which she discusses "repressed behaviors and fears," may be linked to Sigmund Freud's theory of how the unconscious mind functions. The Cinderella Complex is a significant psychological disorder that any woman in the world will encounter at some stage in her life, and it is likely that the world will become more conscious of it.

\section{OBJECTIVE}

1. To analyze research studies on Cinderella complex and to have a deep understanding on the concepts of Cinderella complex and its relative concepts.

\section{METHODOLOGY Literature search}

A computer based information search was conducted which provides abstracts and full paper of articles. Studies from 2016 to 2020 were covered in the search. Google scholar, Research Gate, Napsindia, Semanticscholar, Repository, Academia were searched using "Cinderella complex" and "Cinderella Complex in Women" as keywords to search for papers published from 2016 to 2020. Few studies were identified by the above keywords. Study abstracts obtained were read to eliminate studies that were not concerned with Cinderella complex. These steps produced a pool of 6 studies that met inclusion criteria.

\section{Inclusion Criteria}

The study aimed at understanding the concept of Cinderella Complex. Only full text studies were included. Qualitative studies, articles which focus mainly on Cinderella Complex were also included. Another inclusion criterion was that study must be written in English language.

\section{Procedure}

First of all the selected studies were arranged according to the year of publishing (from 2016 to 2020), then extracted major findings of the studies and then each study was analyzed qualitatively. These selected studies were arranged according to the publishing year. Then they are consolidated and analyzed using content analysis.

\section{RESULTS AND DISCUSSION}

The collected studies were arranged in the order of publication and analyzed using already identified factors and some factors also emerged during the analysis process. The arrangement of selected studies and their classification were presented in table 1 . 
Table 1 Author, title and major findings of Cinderella Complex research papers published during the year 2016 to 2020

\begin{tabular}{|c|c|c|c|}
\hline Sl. No. & $\begin{array}{l}\text { Author(s) } \\
\text { and year }\end{array}$ & $\begin{array}{l}\text { Name of the } \\
\text { study }\end{array}$ & Major findings \\
\hline 1. & $\begin{array}{l}\text { Saha, T Safri } \\
\text { (2016) }\end{array}$ & $\begin{array}{l}\text { inderella Complex: } \\
\text { Theoretical Roots } \\
\text { to Psychological } \\
\text { Dependency } \\
\text { Syndrome in } \\
\text { Women }\end{array}$ & $\begin{array}{l}\text { This kind of realisation in 21st-century women illustrates } \\
\text { the reduced but still important role of dependency in the } \\
\text { female psyche. } \\
\text { It is crucial to undertake research on women's dependence, } \\
\text { as the most recent study on this subject is over } 15 \text { years } \\
\text { old. This definition should be extensively researched on the } \\
\text { Indian population as part of targeted research; research on } \\
\text { this syndrome has not yet been performed in India. }\end{array}$ \\
\hline 2. & $\begin{array}{l}\text { Smith, M. M. S. } \\
\text { (2016). }\end{array}$ & $\begin{array}{l}\text { Cinderella } \\
\text { Complex: A study } \\
\text { on Urban } \\
\text { Homemakers' Life } \\
\text { Satisfaction and } \\
\text { Television } \\
\text { Dependency }\end{array}$ & $\begin{array}{l}\text { This notes that women who are faced with secret } \\
\text { attachment needs are less pleased with their household } \\
\text { tasks, and therefore the assertion 'Most of the things that I } \\
\text { do are tedious or monotonous' confirms the homemakers' } \\
\text { mental state, with the majority of } 75 \text { respondents agreeing. } \\
\text { The relationship between life satisfaction and television } \\
\text { dependence among homemakers has also been discovered. }\end{array}$ \\
\hline 3. & $\begin{array}{c}\text { Sneha, S., \& } \\
\text { Rahmath, F. } \\
\text { (2018) }\end{array}$ & $\begin{array}{l}\text { A Study of } \\
\text { Relationship } \\
\text { between } \\
\text { Cinderella } \\
\text { Complex and } \\
\text { Personal Growth } \\
\text { among Young } \\
\text { Females }\end{array}$ & $\begin{array}{l}\text { It is believed that women with high Cinderella Complex } \\
\text { scores would have a negative attitude toward personal } \\
\text { development. In addition, an interventional strategy to } \\
\text { inspire and train young women for personal growth is } \\
\text { being developed. }\end{array}$ \\
\hline 4. & $\begin{array}{l}\text { V. Chastine \& } \\
\text { N.K. } \\
\text { Darmasetiaw } \\
\text { an (2019) }\end{array}$ & $\begin{array}{c}\text { Cinderella } \\
\text { complex on } \\
\text { working women }\end{array}$ & $\begin{array}{l}\text { The Cinderella complex in participants is mainly triggered } \\
\text { by parental behaviour and patriarchal culture. } \\
\text { Fear of performance, excessive adoration of men, and } \\
\text { achievement discrepancies are all manifestations of the } \\
\text { Cinderella complex. } \\
\text { Participants with the Cinderella complex become reliant, } \\
\text { engage in abusive relationships, and give up their careers } \\
\text { and lives. }\end{array}$ \\
\hline 5. & $\begin{array}{l}\text { Puspitasari, R. } \\
\text { (2019) }\end{array}$ & $\begin{array}{c}\text { A Cinderella } \\
\text { complex issue in } \\
\text { female } \\
\text { protagonist of } \\
\text { Bronte's Jane Eyre } \\
\text { and Meyer's } \\
\text { Twilight : A } \\
\text { psychoanalytic } \\
\text { study }\end{array}$ & $\begin{array}{l}\text { Jane Eyre and Bella Swan both have features of the } \\
\text { Cinderella complex, according to the researcher. They both } \\
\text { have a strong urge to be looked after by someone they care } \\
\text { for. } \\
\text { They begin the story as independent women, but when } \\
\text { they meet men who can help them, they become dependent } \\
\text { women. } \\
\text { Both of them have hidden behaviours and fears as a result } \\
\text { of their traumatic childhood experiences. } \\
\text { Jane Eyre and Bella Swan, in short, both have a Cinderella } \\
\text { complex. }\end{array}$ \\
\hline
\end{tabular}




\begin{tabular}{|c|c|c|c|} 
Husseina, Z. S. & $\begin{array}{c}\text { The Cinderella } \\
\text { Complex as } \\
\text { Reflected in 'The } \\
\text { Grass is Singing' } \\
\text { by Doris Lessing }\end{array}$ & $\begin{array}{l}\text { The Cinderella Complex is a psychological question that } \\
\text { goes unnoticed. Due to patriarchal doctrines that hold } \\
\text { women in a tight circle, desiring only the Prince Charming } \\
\text { who will come and take her to everlasting happiness like } \\
\text { princess Cinderella, it infects women all over the world. In } \\
\text { reality, as the protagonist Mary Turner in The Grass Is } \\
\text { Singing shows, low self-esteem would be the unavoidable } \\
\text { outcome, as she transforms from an independent woman } \\
\text { to a dependent passive wife who lives her life in vain. }\end{array}$ \\
&
\end{tabular}

The bulk of the research, according to the study, was performed on women. When looking at the various types of studies, it's obvious that the majority of them were library analysis, both qualitative and quantitative. Just a few experiments were experimental in nature. The bulk of the research looked into the dimensions, causes, and consequences of Cinderella Complex. The researchers discovered that women should have a wider perspective on their lives and build a personal space for them to spend quality time rejuvenating their own skills and becoming autonomous of their thoughts and acts after evaluating the literature on the Cinderella complex. They could be economically self-sufficient, establish an identity, and become mentally independent women by starting a small business. Furthermore, the researcher suggests that in this age of infotainment, women should rely on the knowledge available and keep informed about current events in order to engage in their family's decision-making process. According to the researcher, women must think deeply about their experiences and discover both the humiliations and the keys to autonomy and reality. Colette Dowling, a New York therapist, invented the term Cinderella Complex (also known as the Cinderella syndrome) in the early 1980s. It's a complex (or syndrome) that makes women think they're 'damsels in distress' who need to be saved from a male suitor. Women wait for a "man" to come along and take care of their lives, so they can live happily and contentedly in the shadows of their men. The Cinderella Complex refers to the largely suppressed attitudes and fears that prohibit women from completely using their minds and imagination, causing them to wait for something or someone outside of themselves to improve their lives. It's likely that women with a strong Cinderella Complex would be reluctant to move on with their lives. As a consequence, the idea of the Cinderella Complex has been shown to be important in today's world. It was noted that it is important to promote research into the Cinderella Complex, since male dependency is common, and the majority of cases and their effects go unnoticed. Cinderella Complex symptoms lead women to enter unrealistic relationships and participate in abusive relationships.

\section{SYMPTOMS OF CINDERELLA COMPLEX}

Most physicians agree that women with this complex also have other deep-seated emotional problems including low self-esteem and dependence issues. Some Cinderella complex sufferers are unable to embrace the men in their lives in a safe way. Rather than viewing them as average people with faults, they often idolise them. This form of idolization often contributes to unreasonable and unattainable expectations. Behaviors can emotionally wound a woman with these unrealistic expectations. Dependency and low self-esteem tend to be the root causes of the issue for women with Cinderella complexes. Most psychologists agree that extreme overprotective parenting can lead to attachment problems in many situations. In fact, these parents' protective actions may have devolved into coercive control, with the child being punished in some cases for showing signs of independence. It's also assumed that women with this complex were socially embarrassed during their formative years, which is a common cause of low self-esteem. These women do not believe they are worth anything other than what their Prince has bestowed upon them. Cinderella Complex victims will still wait for their prince to save them from life; no one else will suffice. They require the male figure to take care of them at all times; they require his care, regardless of the cost. They will remain in an abusive relationship that supports this ideal because they are unable to survive on their own and are terrified of any transition that will split them from their prince. According to Dowling (1981), psychological effects of Cinderella Complex are lack of self esteem, lack of confidence, anxiety and inability to function in the workplace. Cinderella Complex theory's core premise is that we all have a strong desire to be cared about by others. The symptoms may arise as a result of the 
person's psychological state. Repressed behaviours and fears are among the signs.

\section{CONCLUSION}

The definition of the Cinderella complex and its symptoms have acquired a greater understanding thanks to a study of the literature. The majority of studies indicate that all writers approached the issue differently and looked at it from different viewpoints. The Cinderella Complex refers to the largely suppressed attitudes and fears that keep women from fully using their minds and imagination, leading them to wait for something or someone external to change their lives. Women with a heavy Cinderella Complex are likely to be hesitant to move on with their lives. As a result, the Cinderella Complex has been shown to be accurate in today's world; As a person gets older, the complex is said to become more noticeable. Housewives and women who aren't mindful of their surroundings aren't the only ones who have the Cinderella complex. Women who are driven by greed and making a lot of money have a Cinderella Complex. Dependency can be seen in circumstances like depending on a husband for support and deferring all decisions to him. Cinderella Complex tendencies occur in all women, but those with high Cinderella Complex scores are particularly worrying.

\section{IMPLICATIONS AND SUGGESTIONS}

These studies suggest that women should have a broader outlook for their life and create a personal space for them to spend quality time to rejuvenate their own capabilities and be independent in thoughts and actions. Further, the researcher suggests that in this infotainment era women should concentrate on the information available and be informed about current affairs to be a participant in the decision-making process of their family. The researcher puts forth that the women need to have a profound thought about their insights and discover both the humiliations and the keys to autonomy and truth.

Tools for measuring Cinderella complex should be developed. More experimental and qualitative researches should be conducted on this topic. Welfare measures have to be taken for the upbringing of women who are diagnosed with Cinderella complex. Interventions should be conducted for women who are in need for the above.

\section{REFERENCES}

1. Chastine, V., \& Darmasetiawan, N. K. (2019, March). Cinderella complex on working women. In 16th International Symposium on Management (INSYMA 2019) (pp. 103-106). Atlantis Press.

2. Dowling Colette (1981).The Cinderella Complex, Women's hidden fear of independence, pp.3-6, Pocket Books, New York

3. Husseina, Z. S. The Cinderella Complex as Reflected in 'The Grass is Singing'by Doris Lessing.

4. PUSPITASARI, R. (2019). A CINDERELLA COMPLEX ISSUE IN FEMALE PROTAGONISTS OF BRONTE'S JANE EYRE AND MEYER'S TWILIGHT: A PSYCHOANALYTIC STUDY(Doctoral dissertation, UNIVERSITAS SANATA DHARMA YOGYAKARTA).

5. Saha, S., \& Safri, T. S. (2016). Cinderella complex: theoretical roots to psychological dependency syndrome in women. The International Journal of Indian Psychology, 3(3), 118-122.

6. Smith, M. M. S. (2016). Cinderella Complex: A Study of Urban Homemakers' Life Satisfaction and Television Dependency. Mass Communicator: International Journal of Communication Studies, 10(2), 23-27.

7. Sneha, S., \& Rahmath, F. (2018). A Study of Relationship between Cinderella Complex and Personal Growth among Young Females. Indian Journal of Psychological Science, 10(1), 102-107. 